Jurnal Sain Veteriner, Vol. 36. No. 1. Juni 2018, Hal. 103-114

DOI : $10.22146 /$ jsv.38434

ISSN 0126-0421 (Print), ISSN 2407-3733 (Online)

Tersedia online di https://jurnal.ugm.ac.id/jsv

\title{
Deteksi Hemaglutinin, Hemolisin dan Koagulase Secara Fenotipik dan Genotipik pada Staphylococcus aureus Isolat Asal Broiler
}

\section{Phenotypic and Genotypically Detection of Haemagglutinin, Haemolysin and Coagulase of Stapylococcus aureus Isolated from Broiler}

\author{
Khusnan*, Dwi Kusmanto, Agus Purnomo \\ Akademi Peternakan Brahmaputra, Jl. Ki Ageng Pemanahan, Nitikan, \\ Sorosutan Umbulharjo Yogyakarta,Tlp. 0274-384370, \\ *E-mail: khusnanzaini@gmail.com
}

Naskah diterima : 19 Juli 2017, direvisi : 3 April 2018, disetujui : 30 Mei 2018

\begin{abstract}
Staphylococcus aureus is a bacterium causing diseases in animals and human. Staphylococcus aureus in broilers cause septicemia, tendosinovitis, dermatitis, endocarditis, wound infections, arthritis and bumblefoot. In this research, 24 isolates of Staphylococcus aureus from broiler were characterized of its virulent factors including the presence of haemagglutinin, the ability of plasma coagulase, precipitation formation and haemolysis types. By polymerase chain reaction (PCR) were genotypically detected genes coa, clf, hlaA, and hlaB. All of the isolates $(100 \%)$ had haemagglutinin, capable to agglutinate and precipitae of rabbit plasma. All isolates could lyse sheep erythrocytes with the type of $\alpha$-hemolysis (45.8\%), $\beta$-hemolysis $(50.0 \%)$ and $\gamma$-haemolysis $(4.2 \%)$. Genotypically, all isolates $(100 \%)$ had coa and clf genes, hlaAgene $7(0.8 \%)$ and hlaB gene $(29.2 \%)$.
\end{abstract}

Key words: Staphylococcus aureus, broiler, coagulase, hemolysin, haemagglutinin

\begin{abstract}
Abstrak
Staphylococcus aureus merupakan bakteri penyebab penyakit pada hewan dan manusia. Pada broiler Staphylococcus aureus menyebabkan septisemia, tendosinovitis, dermatitis, endokarditis, infeksi luka kulit dan artritis serta bumblefoot. Pada penelitian ini 24 isolat Staphylococcus aureus asal broiler dilakukan karakterisasi faktor virulen secara fenotipik meliputi keberadaan hemaglutinin, kemampuan koagulase plasma, terbentuknya presipitasi dan sifat hemolisis. Secara genotipik digunakan metode polymerase chain reaction (PCR) untuk mendeteksi gen coa, clf, hlaA serta hlaB. Semua isolat Staphylococcus aureus (100\%) memiliki hemaglutinin, mampu menggumpalkan dan mempresipitasi plasma kelinci. Staphylococcus aureus mampu melisiskan eritrosit domba dengan membentuk $\alpha$-hemolisis $(45,8 \%), \beta$-hemolisis $(50,0 \%)$ dan $\gamma$-hemolisis $(4,2 \%)$. Secara genotipik semua isolat (100\%) memiliki gen coa dan clf, 70,8\% isolat memiliki gen hlaA dan $29,2 \%$ gen hlaB.
\end{abstract}

Kata kunci: Staphylococcus aureus, broiler, koagulase, hemolisin, hemaglutinin

\section{Pendahuluan}

Infeksi Staphylococcus aureus telah menjadi masalah dalam industri peternakan unggas (McNamee dan Smyth, 2000), karena menyebabkan kerugian ekonomi (Aziza et al., 2013). Pada ayam potong menyebabkan angka kematian tinggi, menghambat pertumbuhan dan adanya peningkatan beaya pengobatan (Rasheed, 2011). Pada broiler,
Staphylococcus aureus menyebabkan bumblefoot, artritis, septisemia dan tendosinovitis (Vanderhaeghen etal., 2010).

Staphylococcus aureus dalam proses infeksi sampai muncul gejala penyakit ditentukan oleh beragam faktor virulensi yang dimiliki, baik secara fenotip maupun genotip (Gordon dan Lowy, 2008). Secara fenotip faktor virulensi Staphylococcus aureus di antaranya kemampuan koagulase, hemolisis dan 
hemaglutinasi serta keberadaan kapsul polisakarida (de los Santos et al., 2014). Secara genotip virulensi bergantung pada gen-gen virulensi (Diep dan Otto, 2008), dan banyak gen-gen yang mengatur virulensi pada Staphylococcus aureus (Bronner et al., 2004), diantaranya gen coa sebagai gen koagulase (Aslantas et al., 2007), gen clf sebagai gen clumping factor (Vaudaux et al., 1995), serta gen hlaA dan gen hlaB sebagai gen hemolisin (Peacock et al., 2001).

Tujuan penelitian ini mendeteksi keberadaan hemaglutinin secara fenotip, karakter hemolisin, faktor koagulase dan clumping factor secara fenotip dan genotip pada Staphylococcus aureus isolat broiler dengan menggunakan teknik polymerase chain reaction $(\mathrm{PCR})$.

\section{Materi dan Metode}

Penelitian ini menggunakan 24 isolat yang telah diidentifikasi sebagai Staphylococcus aureus (Khusnan dan Kusmanto, 2014). Karakterisasi faktor virulensi secara fenotip dilakukan uji keberadaan hemaglutinin, karakter hemolisis, uji faktor koagulase dengan koagulase tabung serta uji clumping factor secara genotip dilakukan deteksi gen coa, clf, hlaA dan hlaB.

\section{Uji keberadaan hemaglutinin}

Keberadaan hemaglutinin didasarkan kemampuan Staphylococcus aurus dalam mengaglutinasi eritrosit seperti yang dilakukan Wibawan et al. (1992). Digunakan darah kelinci dengan antikoagulan 0,2 M Sodium Sitrat $\mathrm{pH} 5,2$, disentrifus dan dicuci dua kali dengan $0,15 \mathrm{M} \mathrm{NaCl}$, endapan yang berisi eritrosit kemudian dilarutkan menjadi $2 \%$ dengan $\mathrm{NaCl}$. Uji hemaglutinasi dilakukan dengan cara mereaksikan 20 L larutan bakteri yang telah ditentukan optical densitynya dengan spektrofotometer transmisi dan $620 \mathrm{~nm}$ (kira-kira 10 bakteri/mL 0,15 NaCl) dengan 20 L larutan eritrosit di atas gelas obyek. Gelas obyek digoyang selama 30 detik dan reaksi hemaglutinasi dicatat dengan ketentuan sebagai berikut: reaksi kuat, reaksi sedang dan tidak ada reaksi

\section{Keberadaan faktor koagulase secara fenotip dilakukan dengan:}

a. Uji koagulase tabung. Uji ini dilakukan sesuai yang dikerjakan Bruckler et al. (1994), dengan menggunakan plasma kelinci sebanyak $0,5 \mathrm{~mL}$ dalam tabung reaksi dan ditambahkan $0,5 \mathrm{~mL}$ larutan bakteri dari media media Todd Hewitt Broth (THB), diinkubasi selama 6-18 jam pada suhu $37^{\circ} \mathrm{C}$. Pengamatan dilakukan pada jam ke-6 dan dilanjutkan setelah jam ke-18. Staphylococcus aureus akan menunjukkan reaksi positif pada uji koagulase yang ditandai dengan terjadinya gumpalan dalam tabung. Reaksi negatif ditandai dengan tidak terbentuknya gumpalan dalam tabung.

b. Uji clumping factor. Uji ini dilakukan dengan sesuai yang dikerjakan Bruckler et al. (1994), mencampurkan 2 tetes plasma kelinci dan 2 tetes isolat Staphylococcus aureus dari biakan THB pada gelas obyek. Uji clumping factor positif apabila terjadi presipitat dari pencampuran tersebut.

\section{Keberadaan hemolisin}

Uji ini secara fenotip dilakukan seperti yang dikerjakan oleh de los Santos et al. (2014). Isolat Staphylococcus aureus ditanamkan pada pelat agar darah domba steril 5\% (agar base, Oxoid, Jerman). Pelat diinkubasi selama 24 jam pada $37^{\circ} \mathrm{C}$. Zona hemolisis yang terbentuk di sekitar koloni dievaluasi dan dibandingkan dengan standar hemolisis (Microbeonline, 2013).

\section{Deteksi secara genotip,}

Untuk gen koagulase (coa), clumping factor (clf), gen hemolisin (hlaA dan hla $\mathrm{B}$ ) menggunakan teknik 
polymerase chain reaction (PCR) seperti yang dikerjakan Salasia et al. (2011).

\section{Preparasi DNA}

Deoxyribonucleic acid (DNA) Staphylococcus aureus dipreparasi dengan menggunakan Qiamp tissue kit (Qiagen, Hilden, Jerman). Karakterisasi Staphylococcus aureus terhadap gen 23SrRNA dengan menggunakan primer spesies spesifik. Bakteri ditanam pada plat agar darah selama 24 jam pada suhu $37^{\circ} \mathrm{C}, 5-$ 10 koloni bakteri disuspensikan dalam buffer TE (10 mM Tris-HCl, 1 mM EDTA pH 8, yang mengandung 5 $\mu \mathrm{L}$ lysostaphin (1.8 U/ $\mu \mathrm{L}$; Sigma). Setelah inkubasi selama 30 menit pada suhu $37^{\circ} \mathrm{C}$, ditambahkan $25 \mu 1$ of proteinase $\mathrm{K}(14,8 \mathrm{mg} / \mathrm{mL}$; Sigma) dan $200 \mu \mathrm{L}$ of buffer AL (yang berisi reagen AL1 and AL2). Suspensi bakteri diinkubasi ( 3 menit pada suhu $70^{\circ} \mathrm{C}$ dan selama 10 menit pada suhu $95^{\circ} \mathrm{C}$ ), kemudian setelah disentrifus beberapa detik, sebanyak $420 \mu \mathrm{L}$ etanol ditambahkan ke dalam masing-masing sampel dan ditempatkan kedalam kolom QIAamp. Setelah sentrifugasi selama 1 menit kolom QIAamp ditempatkan diatas tabung koleksi dan sampel dicuci dua kali dengan $500 \mu \mathrm{L}$ (Qiagen). Kolom QIAamp kemudian disentrifus selama 3 menit, kolom kemudian ditempatkan diatas $2 \mathrm{ml}$ tabung Eppendorf dan DNA yang ada pada kolom dicuci dua kali dengan cara elusi dengan $200 \mu \mathrm{L}$ buffer AE. Hasil elusi sampel DNA dapat disimpan pada suhu $-20^{\circ} \mathrm{C}$ (Salasia et al., 2004).

\section{Amplifikasi gen coa, clf, hla $\mathrm{A}$ dan hlaB Staphylococcus aureus}

Deteksi gen coa, clf, hlaA dan hlaB melalui amplifikasi dengan menggunakan teknik PCR. Identifikasi gen-gen tersebut pada isolat Staphylococcus aureus ditentukan dengan menggunakan primer spesifik (Tabel 1)

Tabel 1. Primer spesifik untuk gen-gen 23SrRNA, gen coa, gen clf, gen hlaA dan gen hlaB

\begin{tabular}{lll}
\hline Target gen & Sequence (5'-3') & PCR Program \\
\hline 23S & ACG GAG TTA CAA AGG ACG AC & Akineden et al. \\
rRNA & AGC TCA GCC TTA ACG AGT AC & $(2001)$ \\
& ATA GAG ATG CTG GTA CAG G & Baba et al. \\
& GCT TCC GAT TGT TCG ATG C & $(2002)$ \\
& GGC TTC AGT GCT TGT AGG & Boerema et al. \\
& TTT TCA GGG TCA ATA TAA GC & $(2006)$ \\
& GGT TTA GCC TGG CCT TC & Ferens et al. \\
& CAT CAC GAA CTC GTT CG & $(1998)$ \\
& GCC AAA GCC GAA TCT AAG & Ferens et al. \\
& GCG ATA TAC ATC CCA TGG C & $(1998)$ \\
\hline
\end{tabular}

\section{Agarose Gel Electrophoresis}

Sebanyak $10 \mu \mathrm{L}$ produk PCR dicampur dengan $\pm 3 \mu \mathrm{L}$ loading buffer, kemudian dielektroforesis menggunakan agarose $1 \%$ pada tegangan $100 \mathrm{~V}$ selama 30 menit, band DNA pada agar diwarnai dengan larutan ethidium bromide dan divisualisasikan menggunakan UV transilluminator. Besarnya amplikon ditentukan dengan menggunakan marker DNA dan besar amplikon untuk gen-gen tersebut sesuai dengan Salasia et al.(2011).

\section{Hasil dan Pembahasan}

Pada penelitian ini 24 isolat Staphylococcus aureus asal broiler pada uji hemaglutinasi (100\%) memiliki hemaglutinin, seperti (Gambar 1). dan pada uji hemolisis menunjukkan 45,8\% ( $\alpha$-hemolisis), $50,0 \%$ ( $\beta$-hemolisis) dan 4,2\% ( $\gamma$-hemolisis), ( Gambar 2). Pada uji koagulase tabung semua isolat (100\%) menggumpalkan plasma kelinci, (Gambar 3), dan pada uji clumping factor semua isolat (100\%) terbentuk presipitat, (Gambar 4). Secara genotip semua isolat (100\%) memiliki gen coa dan gen clf serta 70,8\% 
terdeteksi memiliki gen hlaA dan 29,2\% memiliki gen hlaB, seperti tersaji pada Tabel 2 .

Uji koagulase tabung, uji clumping factor serta deteksi gen coa dan gen $c l f$ dengan aplikasi PCR merupakan teknik kombinasi yang cepat dan akurat untuk identifikasi virulensi Staphylococcus aureus (Mohamed et al., 2017). Uji-uji ini penting dilakukan untuk menentukan tingkat virulensi Staphylococcus aureus (Mohajeri et al., 2016; Rusenova dan Rusenov, 2017). Pada penelitian ini pada semua isolat menggumpalkan plasma kelinci, membentuk presipitat dan memiliki gen coa dan gen clf.

Proses infeksi Staphylococcus aureus, pertahanan bakteri terhadap fagositosis dan tingkat keparahan penyakit inang dipengaruhi oleh banyak faktor virulen dan sangat kompleks (Diep dan Otto, 2008), di antaranya faktor-faktor yang berhubungan dengan kolonisasi dan adesi (Foster dan Höök, 1998), dan faktor yang berperan pada pertahanan terhadap kekebalan sel-sel fagosit inang (Haveri et al., 2008), serta faktor yang menyebabkan tingkat keparahan gejala penyakit (Dinges et al., 2000).

Enzim koagulase yang dimiliki Staphylococcus aureus merupakan faktor virulensi yang berperan menggumpalkan plasma darah (Babu et al., 2014). Secara in vitro dibuktikan dengan uji koagulase tabung menggunakan plasma kelinci, sehinga terbentuk seperti gel (Aslantas et al., 2007). Staphylococcus aureus yang memiliki enzim koagulase lebih patogen dibandingkan dengan Staphylococcus aureus mutan dengan inaktivasi dengan koagulase (Moreillon et al., 1995). Inaktivasi atau netralisasi enzim koagulase dapat menghilangkan sifat patogenesis Staphylococcus aureus (McAdow et al., 2012).

Secara genotip kemampuan koagulase diatur dengan gen coa (Tiwari et al., 2008), keberadaan gen coa ini merupakan faktor virulensi yang penting pada Staphylococcus aureus (Babu et al., 2014). Gen coa merupakan gen adesin pada Staphylococcus aureus yang berperan penting pada proses infeksi, yaitu berperan dalam kolonisasi dan invasi pada sel inang (Peacock et al., 2002). Gen coa berperan dalam mekanisme pertahanan Staphylococcus aureus terhadap sel-sel fagositosis inang (Aarestrup et al., 1995), yaitu dengan mengaktifkan protrombin sebagai anti fagositosis (Engleberg et al., 2006), gen coa berperan menghalangi fagositosis oleh sel neutrofil inang maupun sel kekebalan lainnya (Guggenberger $e t$ al., 2012), sehingga bakteri mampu bertahan hidup, akan memperbanyak diri dalam proses infeksi (Aarestrup et al., 1995). Karakulska et al. (2011) melaporkan gen coa terdeteksi pada semua Staphylococcus aureus isolat asal sapi perah.

Clumping factor atau faktor penggumpal merupakan faktor virulensi pada Staphylococcus aureus (Perkins et al., 2001), yang diatur oleh gen clf (Vancraeynest et al., 2006), yang berperan sebagai faktor adesin pada awal proses infeksi (Flick et al., 2013), serta berperan pada pembekuan darah dan kerusakan sel permukaan inang (Moreillon et al., 1995), dan menghambat proses fagositosis oleh makrofag (Higgins et al., 2006). Clumping factor dilaporkan sering ditemukan pada sebagian besar isolat Staphylococcus aureus (Salasia et al., 2004)

Pada penelitian ini 100\% terdeteksi memiliki gen clf. Hasil ini sama dengan laporan Elsayed et al. (2015) dan Almeida et al. (2013) Staphylococcus aureus asal susu sapi dan kerbau serta domba 100\% memiliki gen clf. Salasia et al. (2004) melaporkan $64,3 \%$ Staphylococcus aureus terdeteksi memiliki gen clf.

Hemolisin pada Staphylococcus aureus sebagai faktor virulensi penting yang berkontribusi pada proses invasi, meningkatkan keparahan penyakit dan perlindungan diri dari respon imun inang. Pada penelitian ini secara fenotip semua isolat Staphylococcus aureus memiliki hemolisin dengan 
distribusi $\alpha$-hemolisis (45,8\%), $\beta$-hemolisis $(50,0 \%)$ dan $\gamma$-hemolisis $(4,2 \%)$. Secara genotip distribusi gen hlaA (70,8\%) dan gen hla $\mathrm{B}(29,2 \%)$.

Hasil penelitian ini secara fenotip berlawanan seperti yang dilaporkan Abdalrahman et al. (2015), yaitu distribusi $\alpha$-hemolisis lebih banyak dari pada $\beta$ hemolisis. Secara umum distribusi $\alpha$-hemolisis lebih banyak diproduksi oleh Staphylococcus aureus isolat asal hewan (Ariyanti et al., 2011). Distribusi $\alpha$ hemolisis Staphylococcus aureus isolat asal sapi lebih besar daripada $\beta$-hemolisis (Cifrian et al., 1996). Distribusi $\alpha$-hemolisis lebih besar dari pada $\beta$ hemolisis pada Staphylococcus aureus yang berasal dari infeksi akut, sub akut maupun kronis (Tirpude dan Batra, 2012).

Tabel 2. Karakterisasi fenotip dan deteksi gen koagulase (coa), clumping factor (clf), hlaA dan hlaB pada Staphylococcus aureus isolat broiler

\begin{tabular}{|c|c|c|c|c|c|c|c|c|c|c|c|c|}
\hline & kode & & & & & & & & & noti & & \\
\hline & isolat & $\begin{array}{c}\text { Hem } \\
\text { aglu } \\
*\end{array}$ & $\alpha$ & $\beta$ & $\gamma$ & $\begin{array}{l}\text { KT } \\
* *\end{array}$ & $\begin{array}{l}\text { clf } \\
* * *\end{array}$ & $\begin{array}{c}23 \mathrm{~S} \\
\text { rRNA }\end{array}$ & coa & clf & hlaA & hlaB \\
\hline 1 & BFT120 & + & & + & & + & + & + & + & + & + & \\
\hline 2 & BFT23 & + & + & & & + & + & + & + & + & + & \\
\hline 3 & BFT24 & + & & + & & + & + & + & + & + & + & \\
\hline 4 & KB31 & + & + & & & + & + & + & + & + & + & \\
\hline 5 & KB32 & + & & + & & + & + & + & + & + & + & \\
\hline 6 & KB62 & + & + & & & + & + & + & + & + & & + \\
\hline 7 & KB63 & + & & + & & + & + & + & + & + & + & \\
\hline 8 & KB80 & + & & + & & + & + & + & + & + & + & \\
\hline 9 & KB81 & + & & + & & + & + & + & + & + & + & \\
\hline 10 & M3 & + & & + & & + & + & + & + & + & + & \\
\hline 11 & M5 & + & & + & & + & + & + & + & + & & + \\
\hline 12 & T106 & + & & + & & + & + & + & + & + & + & \\
\hline 13 & $\mathrm{~T} 103$ & + & & + & & + & + & + & + & + & + & \\
\hline 14 & T104 & + & & + & & + & + & + & + & + & + & \\
\hline 15 & BF6 & + & + & & & + & + & + & + & + & & + \\
\hline 16 & BF9 & + & + & & & + & + & + & + & + & & + \\
\hline 17 & BF16 & + & & + & & + & + & + & + & + & + & \\
\hline 18 & K10 & + & + & & & + & + & + & + & + & & \\
\hline 19 & K13 & + & + & & & + & + & + & + & + & + & \\
\hline 20 & Art4 & + & & & + & + & + & + & + & + & & \\
\hline 21 & Art6 & + & + & & & + & + & + & + & + & + & \\
\hline 22 & Art7 & + & + & & & + & + & + & + & + & + & + \\
\hline 23 & Art9 & + & + & & & + & + & + & + & + & + & \\
\hline 24 & Art11 & + & + & & & + & + & + & + & + & + & \\
\hline
\end{tabular}

*hemaglutinasi $\quad * *$ koagulase tabung $* * *$ clumping factor
Hemolisin merupakan eksotoksin yang dimiliki Staphylococcus aureus (Moraveji et al., 2014), yang berupa protease ekstraseluler (Kolar et al., 2013). Hemolisin merupakan racun yang dapat melisiskan eritrosit dan pada pelat agar darah akan membentuk zona hemolisis (Bhakdi et al., 1989). Hemolisin merupakan faktor virulensi yang penting pada Staphylococcus aureus (Kolar et al., 2013; dan berperan penting dalam patogenesis (Moraveji et al., 2014), serta memberikan kontribusi menyebabkan tingkat keparahan penyakit (Da Silva et al., 2005). 
Hemolisin berperan dalam meningkatkan permiabilitas sel, sehingga sel lebih rentan terhadap agen infeksi (Park et al., 2004), dan berperan dalam perlekatan pada sel inang serta mempercepat penetrasi bakteri pada sel inang (Fiaschi et al., 2016), serta mempunyai kemampuan melisiskan sel darah merah (Bhakdi et al., 1989). Hemolisin berperan dalam pertahanan diri terhadap respon imun inang (Da Silva et al., 2005), dan berperan dalam menghancurkan berbagai sel imun, seperti monosit (Bhakdi et al., 1989), dan makrofag (Kolar et al., 2013).

Tingkat virulensi Staphylococcus aureus tergantung kepada jenis produksi hemolisin, menurut Leitner et al. (2003) tingkat virulensi hemolisin berturut-turut $\alpha$-hemolisin, $\beta$-hemolisin kemudian $\gamma$ -

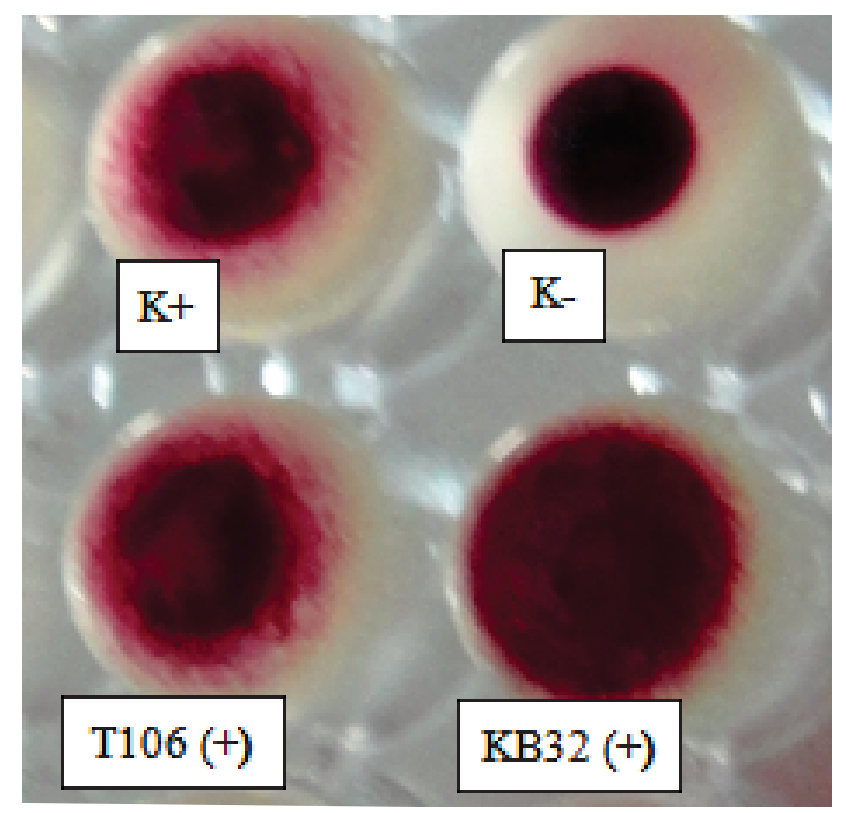

Gambar 1. Uji hemaglutinasi pada S. aureus $(\mathrm{K}-)=$ kontrol negatif eritrosit mengendap $(\mathrm{K}+)=$ kontrol positif terjadi hemaglutinasi

Menurut Dinges et al. (2000) $\alpha$-hemolisin memiliki peran hemolitik, dermonekrotik dan neurotoksik, sedangkan $\beta$-hemolisin merupakan sphingomyelinase yang berperan dalam melisiskan eritrosit (Larsen et al., 2002). Secara genotip hemolisin pada Staphylococcus aureus dikodekan sebagai gen hemolisin. $\alpha$-hemolisin dan $\beta$-hemolisin sebagai faktor virulensi yang penting pada Staphylococcus aureus (Burnside et al., 2010), yang dapat menyebabkan kerusakan sel dan berperan dalam peradangan sampai nekrosis epitel pernafasan (Hayashida et al.. 2009).

Secara fenotip dengan menggunakan media agar darah hemolisin Staphylococcus aureus akan membentuk zona hemolisis spesifik yang dapat diidentifikasi sebagai $\alpha$-hemolisis, $\beta$-hemolisis, $\gamma$ hemolisis dan $\delta$-hemolisis (Burnside et al., 2010). $\alpha$ hemolisin merupakan hemolitik, dermonekrotik dan aktivitas neurotoksik dan dianggap utama faktor patogenitas Staphylococcus aureus (Dinges et al., 2000). $\beta$-hemolisin adalah sphingomyelinase yang menyebabkan lisisnya eritrosit (Larsen et al., 2002).

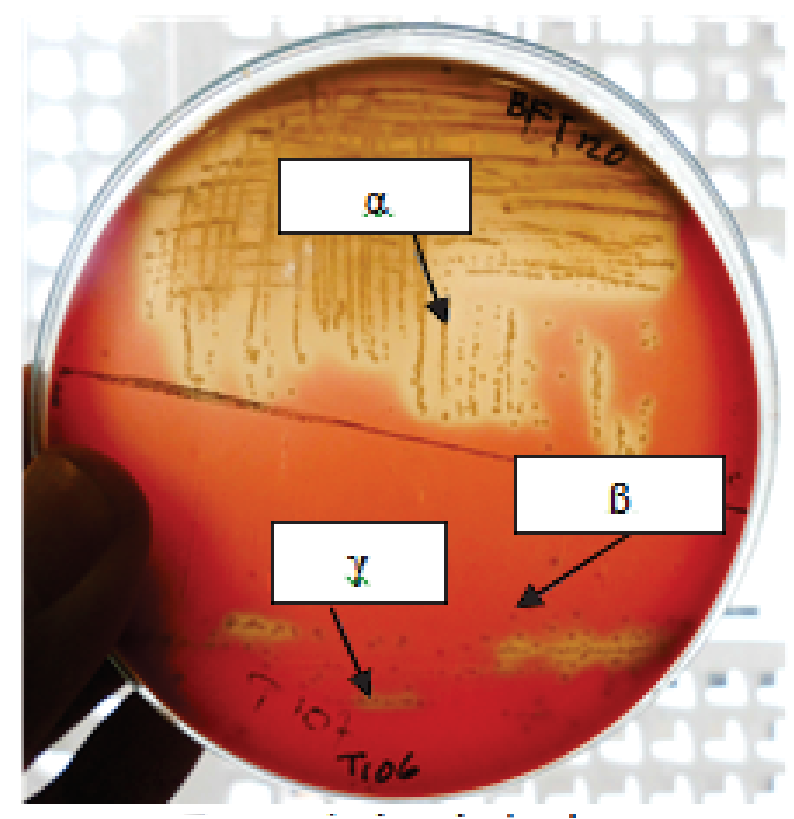

Gambar 1. Pertumbuhan koloni S. aureus pada media agar darah terjadi zona hemolisis $\alpha$-hemolisin (Kb62) $\beta$-hemolisin (T106) $\gamma$-hemolisis (Art4)

hlaA dan gen hlaB (Kumar et al. 2011). Pada penelitian ini dengan menggunakan teknik polymerase chain reaction (PCR) diperoleh hasil semua isolat memiliki gen hemolisin, dengan distribusi gen hlaA(70,8\%) dan gen hlaB (29,2\%), dengan amplikon gen hla $\mathrm{A}(704 \mathrm{bp})$ dan hlaB (496bp). Hasil penelitian ini menunjukkan 
distribusi gen hlaA lebih tinggi dari pada gen hlaB. Distribusi gen hlaA lebih tinggi dari pada gen hla $\mathrm{B}$ telah dilaporkan Delgado et al. (2011) dan Almeida et al. (2013). Abdalrahman et al. (2015) melaporkan distribusi gen hlaA dan hlaB pada Staphylococcus aureus isolat asal bangsa burung sebesar $75.6 \%$ dan $41.7 \%$, pada anak ayam $81,2 \%$ dan $38,2 \%$, pada kalkun sebasar $67,2 \%$ dan $46,3 \%$

Hasil penelitian ini menunjukkan tidak ada hubungan antara distribusi hemolisis secara fenotip dengan genotip. Secara fenotip $\alpha$-hemolisis (45,8\%), $\beta$-hemolisis $(50,0 \%)$ dan $\gamma$-hemolisis $(4,2 \%)$, tetapi secara genotip gen hlaA $(70,8 \%)$ dan gen hlaB (29,2\%). Perbedaan distribusi karakter hemolisis pada Staphylococcus aureus antara fenotip dan genotip telah dilaporkan oleh Fei et al. (2011) bahwa distribusi $\alpha$ hemolisis secara fenotip $(43,4 \%)$ dan secara genotip gen hla $\mathrm{A}(88 \%)$, sedangkan $\beta$-hemolisis (43\%) dan gen hlaB (42,6\%). Adanya perbedaan distribusi antara fenotip dan genotip mungkin dipengaruhi oleh banyak faktor, di antaranya karena mutasi gen (Ariyanti et al., 2011).

Pada uji hemaglutinasi semua isolat Staphylococcus aureus menggumpalkan eritrosit kelinci, artinya semua isolat Staphylococcus aureus yang diteliti memiliki hemaglutinin. Hemaglutinin dari Staphylococcus aureus itu ditentukan berdasarkan haemagglutination reaction (Salasia dan Laemmler, 1995). Hemaglutinin merupakan protein permukaan dan berperan sebagai adesin Staphylococcus aureus (Rares, 2011). Hemagutinin merupakan faktor virulensi pada Staphylococcus aureus, yaitu mempermudah Staphylococcus aureus untuk beradesi pada sel jaringan inang (Gatermann et al., 1992) dan perlekatan bakteri pada pemukaan sel darah merah (Abrar et al., 2013), dan berperan awal pada proses infeksi (Harshini, 2015). Keberadaan hemaglutinin pada Staphylococcus aureus dikaitkan dengan patogenesis (Rupp dan Archer, 1995).

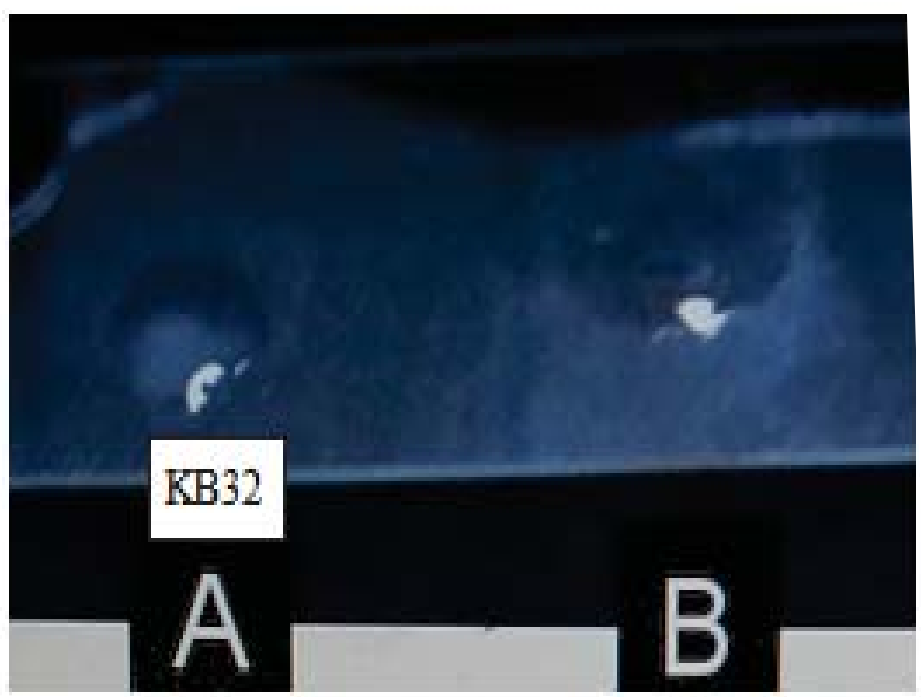

Gambar 4. Uji clumping factor menggunakan plasma kelinci $(\mathrm{A})=$ terjadi presipitasi $(\mathrm{B})=$ kontrol negatif 


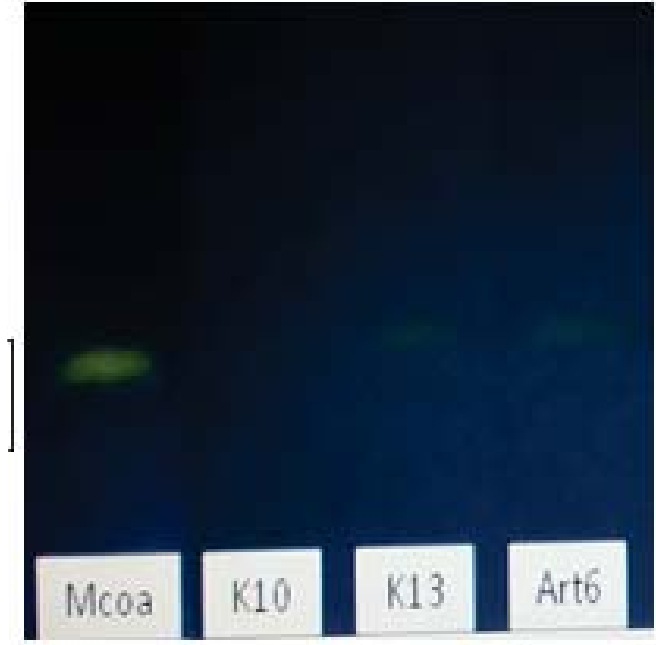

Gambar 5. Analisis gen coa (199bp) pada S. aureus

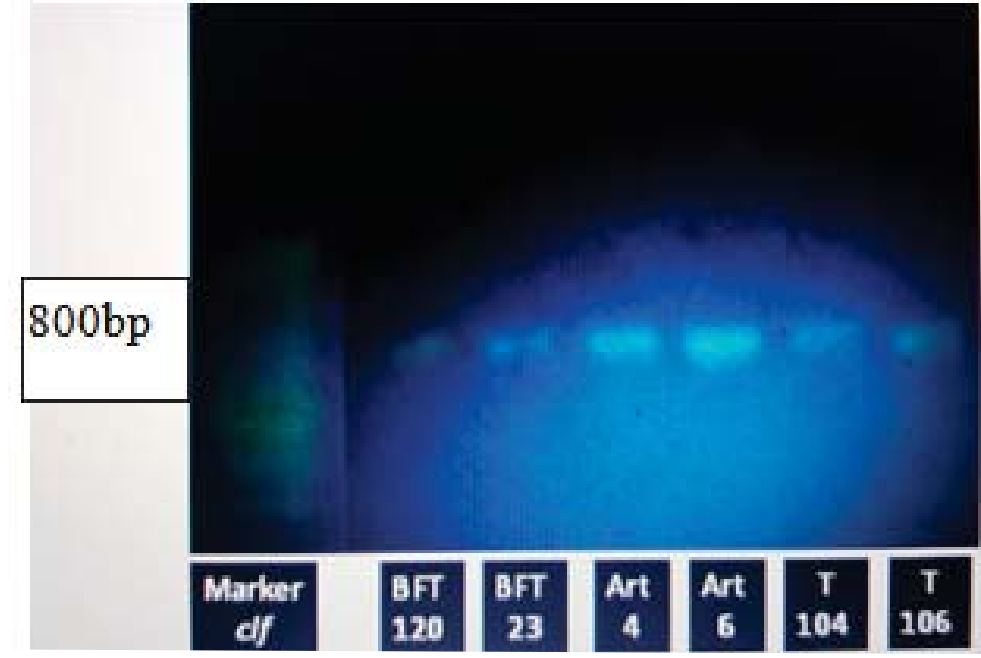

Gambar 6. Analisis gen clf(800bp) pada $S$. aureus

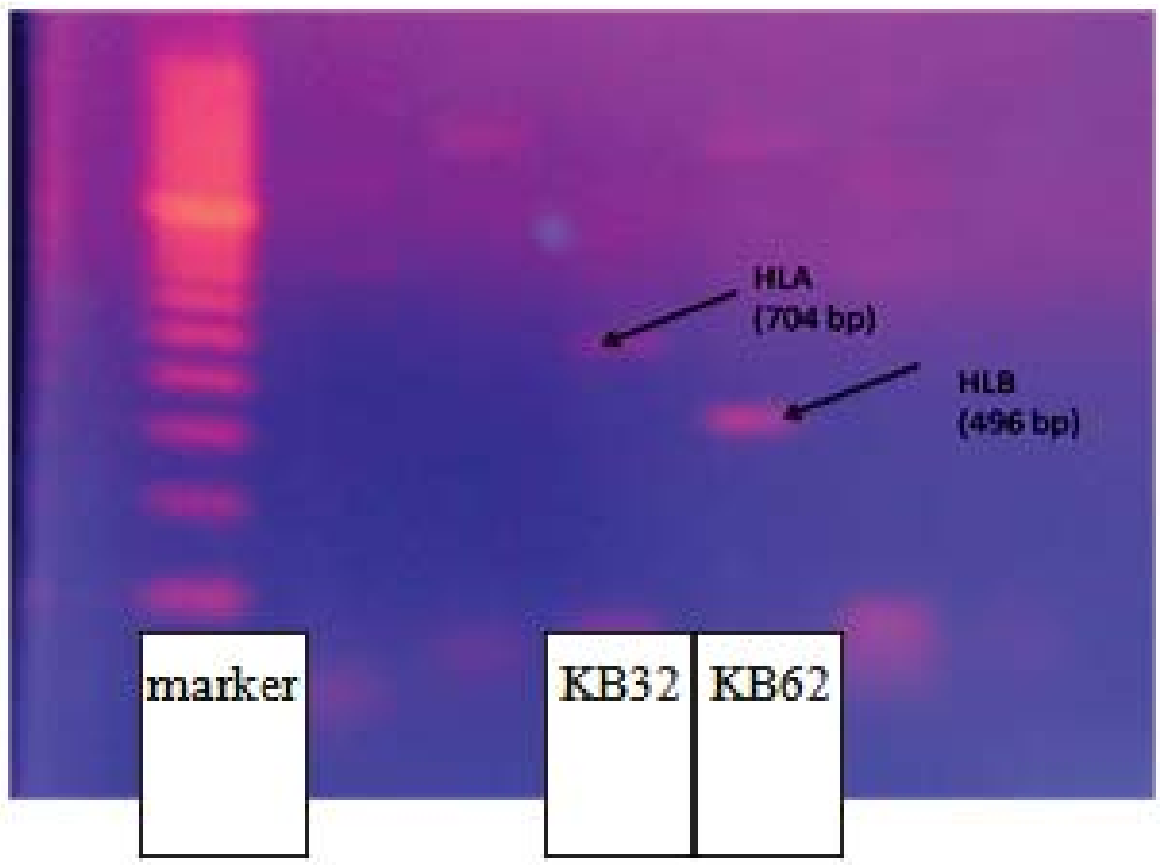

Gambar 7. Analisis gen hlaA (704bp) dan gen hlaB (496bp) pada S. aureus

Staphylococcus aureus memiliki banyak faktor virulensi yang berupa eksoprotein seperti eksotoksin dan enzim, diantaranya nukleases, protease, lipase, hialuronidase dan kolagenase serta koagulase yang semuanya dapat mempengaruhi tingkat patogenisitas (El-Hamid dan Bendary, 2013). Banyaknya faktor virulen yang dimiliki oleh Staphylococcus aureus dapat peningkatan tingkat virulensi sehingga menimbulkan kejadian penyakit yang lebih parah sampai menimbulkan kematian inang (Kolar et al., 2013). Menurut Franco et al. (2008) bakteri yang memiliki banyak faktor virulen akan lebih bersifat virulen dan dapat meningkatkan sifat patogenenisitas bakteri karena virulensi Staphylococcus aureus bersifat multi faktorial. Patogenisitas Staphylococcus aureus merupakan proses yang kompleks dan melibatkan beragam faktor virulensi (Cotar et al., 2010).

\section{Kesimpulan}

Berdasarkan faktor-faktor virulensi yang dideteksi Staphylococcus aureus isolat asal broiler bersifat virulen. Isolat-isolat tersebut terdeteksi memiliki hemaglutinin, memiliki hemolisin dan 
memiliki faktor penggumpal secara fenotip maupun genotip.

\section{Ucapan Terima Kasih}

Publikasi ini merupakan sebagian dari hasil Penelitian Fundamental yang dibiayai oleh DP2M Dikti Kementerian Pendidikan dan Kebudayaan tahun anggaran 2011-2012. Kepada: Arisa Diana Ekawati, Dianita Dwi Sugiartini, Eka Yanuarti dan Imam Hanafi diucapkan terimakasih atas bantuannya.

\section{Daftar Pustaka}

Aarestrup, F.M., Dangler, C.A. and Sordillo, L.M. (1995) Prevalence of coagulase gene polymorphism in Staphylococcus aureus isolates causing bovine mastitis. Can. J. Vet. Res., 59:124-128.

Abdalrahman, L.S., Stanley, A., Wells, H. and Fakhr, M.K. (2015) Isolation, virulence, and antimicrobial resistance of methicillinresistant Staphylococcus aureus (MRSA) and methicillin sensitive Staphylococcus aureus (MSSA) strains from Oklahoma retail poultry meats. Int. J. Environ. Res. Public Health. 12: 6148-6161.

Abrar, M., Wibawan, I.W.T., Priosoeryanto, B.P., Soedarwanto, M. and Pasaribu. F.H. (2013) Role of Staphylococcus aureus haemaglutinin in adhesion process on udder epithelial cells. J. Kedokteran Hewan, 7(1): 43-46.

Akineden, O., Annemuller, C., Hassan, A.A., Laemmler, C., Wolter, W. and Zschöck, M. (2001) Toxin genes and other characteristics of Staphylococcus aureus isolates from milk of cows with mastitis. Clin. Diagn. Lab Immunol., 8: 959-964.

Almeida, L.M., de Almeida, M.Z., de Mendonca, C.L. and Mamizuka, E.M. (2013) Comparative analysis of agr groups and virulence genes among subclinical and clinical mastitis Staphylococcus aureus isolates from sheep flocks of the Northeast of Brazil. Brazilian Journal of Microbiology . 44(2):493-498.

Ariyanti, D., Salasia, S.I.O. and Tato, S. (2011) Characterization of haemolysin of Staphylococcus aureus isolated from food of animal Origin. Indon. J. of Biotech., 16(1): 32-37.
Aslantas, O., Demir, C., Turutoglu, H., Cantekin, S., Ergun, Y. and Dogruer, G. (2007) Coagulase gene polymorphism of Staphylococcus aureus isolated form sub clinical mastitis. Turk. J. Vet. Anim. Sci. 31:253-257.

Aziza, A.M.S., Akter, M.R., Rahaman, M.S., Mas, K., Zakm, H., Jahan, M.S. and Kabir, L.S.M. (2013) Isolation, identification and antibiogram profiles of Staphylococcus aureus from commercial broiler flocks in Dinajpur District of Bangladesh with special focuson the determination of lethal effect of extracted toxin. Sci. J. of Microbiol. 2(4): 7482.

Baba, T., Takeuchi, F., Kuroda, M., Yuzawa, H., Aoki, K., Oguchi, A., Nagai, Y., Iwama, N., Asano, K., Naimi, T., Kuroda, H., Cui, L., Yamamoto, K. and Hiramatsu, K. (2002) Genome and virulence determinants of high virulence community-acquired MRSA. Lancet, 359: 1819-1827.

Babu, N.G.R., Shree G.B.B., Rekha L. and Karthiga P. (2014) Molecular analysis of coagulase (coa) gene polymorphism in clinical isolates of Staphylococcus aureus by PCR-RFLP. Int. J. of Innov. Res. in Sci., Eng. and Technol., 8162-8168.

Bhakdi, S., Muhly, M., Korom, S. and Hugo, F. (1989) Release of interleukin-1 associated with potent cytocidal action of staphylococcal alpha-toxin on human monocytes. Infect. Immun., 57: 3512-3519.

Boerema, J.A, Clemens, R. and Brightwell, G. (2006) Evaluation of molecular methods to determine enterotoxigenic status and molecular genotype of bovine, ovine, human and food isolates of Staphylococcus aureus. Int. J. Food Microbiol., 107: 192-201.

Bronner, S., Monteil, H. and Prevost, G. (2004) Regulation of virulence determinants in Staphylococcus aureus: complexity and applications. FEMS Microbiol. Rev., 28(2): 183-200.

Brückler, J., Schwarz, S. and Untermann, F. (1994) St a phylokokken-Infektionen und-Enterotoxine, Band. II/1, In Blobel, $\mathrm{H}$. und Schlieer (eds.), Handbuch der bakteriellen Infektionen bei Tieren, 2. Auflage. Gustav Fischer Verlag Jena, Stuttgart. 
Burnside, K., Lembo, A., de los Reyes, M., Iliuk, A., Nguyen-Thao, B., Connelly, J.E., Wan-Jung, L., Schmidt, B.Z., Richardson, A.R., Fang, F.C., Tao, W.A. and Rajagopal, L. (2010) Regulation of hemolysin expression and virulence of Staphylococcus aureus by a serine/threonine kinase and phosphatase. http://dx.doi.org/10.1371/journal.pone.0011 071

Cifrian, E., Guidry, A.J., Bramley, A.J., Norcross, N.L., Bastida-Corcuera, F.D. and Marquardt, W.W. (1996) Effect of staphylococcal alpha toxins on the cytotoxicity, proliferation and adherence of Staphylococcus aureus to bovine mammary epithelial cells. Vet. Microbiol. 48:187-198.

Cotar, A.I., Chifiriuc, M.C., Dinu, S., Bucur, M., Iordache , C., Banu, O., Dracea, O., Larionand, C. and Lazar, V. (2010) Screening of molecular virulence markers in Staphylococcus aureus and Pseudomonas aeruginosa strains isolated from clinical infections. Int. J. Mol. Sci., 11(12): 52735291.

Da Silva, R.E., Boechat, J.U.D., Martins, J.C.D., Ferreira, W.P.B., Sequera, A.P.S. and Da silva N. (2005) Hemolysin production by Staphylococcus aureus species isolated from mastitic goat milk in Brazilian Dairy Herd. Sci. Small rum. res., 56: 271-275.

De los Santos, Fernández, M., Carro, S. and Zunino, P. (2014) Characterisation of Staphylococcus aureus isolated from cases of bovine subclinical mastitis in two Uruguayan dairy farms. Arch. Med. Vet., 46: 315-320.

Delgado, S., Garcia P., Fernandez, L., Jimenez, E., Rodriguez-Banos, M., Del Campo, R. and Jrodriguez, J.M. (2011) Characterization of Staphylococcus aureus strains involved in human and bovine mastitis. Immunol. Med. Microbiol., 62: 225-235.

Diep, B.A. and Otto, M. (2008). The role of virulence determinants in community-associated MRSA pathogenesis. Trends in Microbiol., 16(8): 361-369.

Dinges, M.M., Orwin, P.M. and Schlievert, P.M. (2000) Exotoxins of Staphylococcus aureus. Clin. Microbiol. Rev., 13:16-34.
El-Hamid, M.I.A. and Bendary, M.M. (2013) Association between agr alleles and toxin gene profiles of $S$. aureus isolates from human and animals sources in Egypt. Int. J. of Adv. Res., 1(8): 133-144.

Elsayed, M,S., El-Bagoury, A.M. and Dawoud, M.A. (2015) Phenotypic and genotypic detection of virulence factors of Staphylococcus aureus isolated from clinical and subclinical mastitis in cattle and water buffaloes from different farms of Sadat City in Egypt, Vet. World, 8(9): 1051-1058.

Engleberg, N.C., DiRita, V. and Dermody, T.S. (2006) Schaechter's Mechanisms of Microbial Disease. Fourth edition. Chapter 11: 147-155.

Fei, W., Hongjun, Y., Hong-bin, H., Changfa, W., Yundong, G., Qifeng, Z., Xiaohong, W. and Yanjun, Z. (2011) Study on the haemolysin phenotype and the genotype distribution of Staphylococcus aureus caused bovine mastitis in Shandog dairy farms. Int. J. Appl. Res. Vet. M., 9(4): 416-421

Ferens, W.A., Davis, W.C., Hamilton, M.J., Park, Y.H., Deobald, C.F. and Fox, L. (1998) Activation of bovine lymphocyte subpopulations by staphylococcal enterotoxin C. Infect. Immun. 66: 573-580.

Fiaschi, L., Di Palo, B., Scarselli, M., Pozzi, C., Tomaszewski, K., Galletti, B., Nardi-Dei, V., Arcidiacono, L., Mishra, R.P.N., Mori, E., Pallaoro, M., Falugi, F., Torre, A., Fontana, M.R., Soriani, M., Wardenburg, J.B., Grandi, G., Rappuoli, R., Ferlenghi, I. and Bagnoli, F. (2016) Auto-assembling detoxified Staphylococcus aureus alpha-hemolysin mimicking the wild-type cytolytic toxin. Clin. Vaccine Immunol., 23: 442-450.

Flick, M.J., Du, X., Prasad, J.M., Raghu, H., Palumbo, J.S., Smeds, E., Hook, M. and Degen, J.L. (2013) Genetic elimination of the binding motif on fibrinogen for the $S$. aureus virulence factor clfA improves host survival in septicemia. Blood. 121: 1783-1794.

Foster, T.J. and Hook, M. (1998) Surface protein adhesins of Staphylococcus aureus. Trends Microbiol. 6: 484-488.

Franco, G.J.C., Gonzalez, V.L.G., Gomez, M.S.C., Carrillo, G.J.M. and Ramirez, C.J.J. (2008) Virulence factors analysis of Staphylococcus 
aureus isolated from bovine mastitis in Mexico. eGnosis [online] 6, Art. 7. http://www.redalyc.org/pdf/730/730111970 07.pdf

Gatermann, S.G., Kreft, B., Marre, R. and Wanner, G. (1992) Identification and characterization of a surface-associated protein (ssp) of Staphylococcus saprophyticus. Infect. Immun. 60: 1055-1060.

Gordon, R. and Lowy, F.C. (2008) Pathogenesis of methicillin-resistant Staphylococcus aureus infection. Clin. Infect. Dis. 46:350-359.

Guggenberger, C., Wolz, C., Morrissey, J.A., and Heesemann, J. (2012) Two distinct coagulase-dependent barriers protect Staphylococcus aureus from neutrophils in a three dimensional in vitro infection model. PLoS Pathog., 8: e1002434 2012

Harshini, A.K. (2015) Adhesion in Bacteria. Int J. of Sciandres., 279-281.

Haveri, M., Hovinen, M., Roslof, A., Pyorala, S. (2008) Molecular types and genetic profiles of Staphylococcus aureus strains isolated from bovine intramammary infections and extramammary sites. J. Clin. Microbiol., 46: 3728-3735.

Hayashida, A., Bartlett A.H., Foster T.J. and Park P.W. (2009) Staphylococcus aureus beta-toxin induces lung injury through syndecan-1. Am. J. Pathol. 174: 509-518.

Higgins J., Loughman, A., van Kessel, K.P.M., van Strijp, A.G. and Timothy, J. (2006) Foster clumping factor A of Staphylococcus aureus inhibits phagocytosis by human polymorphonuclear leucocytes. FEMS. Microbiol. Lett., 258: 290-297.

Karakulska, J., Pobucewicz, A., Nawrotek, A., Muszyńska, M., Furowicz, A.J. and Furowicz D.C. (2011) Molecular typing of Staphylococcus aureus based on PCR-RFLP of coa gene and RAPD analysis. Pol. J. Vet. Sci., 14:285-286.

Khusnan dan Kusmanto, D. (2014) MethicillinResistant Staphylococcus aureus (MRSA) Isolat ayam pedaging dan kajian virulensi pada sel hospes secara invivo dan invitro. Laporan Penelitian Fundamental 2013-2014. Kemendikbud. Republik Indonesia
Kolar, S.L., Ibarra, J.A., Rivera, F.E., Mootz, J.M., Davenport, J.E., Stevens, S.M., Horswill, A.R. and Shaw, L.N. (2013) Extracellular proteases are key mediators of Staphylococcus aureus virulence via the global modulation of virulence determinant stability. Microbiol. Open., 2:18-34.

Kumar, R., Yadav, B.R. and Singh, R.S. (2011) Antibiotic resistance and pathogenicity factors in Staphylococcus aureus isolated from mastitic sahiwal cattle.J. Biosci 36(1):175-188.

Larsen, H.D., Aarestrup, F.M. and Jensen, N.E. (2002) Geographical variation in the presence of genes encoding superantigenic exotoxins and beta-hemolysin among Staphylococcus aureus isolated from bovine mastitis in Europe and USA. Vet. Microbiol., 85: 61-67.

Leitner, G., Krifucks, O., Glickman, A., Younis, A. and Saran, A. (2003) Staphylococcus aureus strains isolated from bovine mastitis: virulence, antibody production and protection from challenge in a mouse model. Immunol. and Med. Microbiol., 35:99-106.

McAdow, M., Missiakas D.M. and Schneewind, O. (2012) Staphylococcus aureus secretes coagulase and von willebrand factor binding protein to modify the coagulation cascade and establish host infections. J. Innate. Immun., 4: 141-148

McNamee, P.T. and Smyth, J.A. (2000) Bacterial chondronecrosis with osteomylitis (femoral head necrosis) of broiler chickens: a review. Av. Pathol. 29(5): 477-495.

Microbeonline (2013) Blood Agar: Composition, preparation, uses and types of hemolysis. http://microbeonline.com/blood-agarcomposition-preparation-uses-and-types-ofhemolysis

Mohajeri, P., Azizkhani, S., Farahani, A. and Norozi, B. (2016) Genotyping of coa and aroA Genes of Methicillin-Resistant Staphylococcus aureus Strains Isolated From Nasal Samples in Western Iran. Jundishapur J. Microbiol., 9(1): e26460

Mohan, K., Shroeder-Tucker, L.C., Karenga, D., Dziva, F., Harrison, A. and Muvavarirwa, P. (2002) Un-identified Coryne form Bacterial strain from cases of polyarthritis in chickens: 
phenotype and fatty acid profile. Avian Dis. 46:1051-1054.

Mohamed, S.R., Habashy, H.F., El-Shahawy, H.S. and Salem, N.I.E. (2017) Phenotype and genotype characterization of staphylococcus aureus causing sub clinical mastitic cattle milk using vitek 2 compact system and PCR. An. Health Res. J. 5(1): 86-96.

Moreillon, P., Entenza, J.M., Francioli, P., Mcdevitt, D., Foster, T.J., Francois, P. and Vaudaux, P. (1995) Role of Staphylococcus aureus coagulase and clumping factor in pathogenesis of experimental endocarditis. Am. Soc. for Microbiol. Infect. and Immun., 63: 4738-4743.

Park, P.W., Foster, T.J., Nishi, E., Duncan, S.J., Klagsbrun, M. and Chen, Y. (2004) Activation of syndecan-1 ectodomain shedding by Staphylococcus aureus $\alpha$-toxin and $\beta$-toxin. J. Biol. Chem. 279(1): 251-258.

Peacock, S.J., de Silva, I. and Lowy, F.D. (2001) What determines nasal carriage of Staphylococcus aureus? Trends Microbiol., 9: 605-610.

Perkins, S., Walsh, E.J., Deivanayagam, C.C., Narayana, S.V., Foster, T.J. and Hook, M. (2001) Structural organization of the fibrinogen-binding region of the clumping factor B MSCRAMM of Staphylococcus aureus. J. Biol. Chem., 276: 44721-44728.

Rares, F.E.S. (2011) Deteksi hemaglutinin protein permukaan Staphylococcus aureus dengan menggunakan eritrosit Rattus novergicus strain wistar. J. Biomedik, 3(3): 156-164. (abstract)

Rasheed, B.Y. (2011) Isolation and identification of bacteria causing arthritis in chickens Iraqi $J$. of Vet. Sci., 25(2): 93-95.

Rupp, M.E. and Archer, G.L. (1995) Hemagglutination and adherence to plastic by Staphylococcus epidermidis. Infect. Immun., 60: 4322-432.

Rusenova, N.V. and Rusenov, A.G. (2017) Detection of Staphylococcus aureus among coagulase positive staphylococci from animal origin based on conventional and molecular methods. Mac. Vet. Rev., 40(1): 29-36.

Salasia, S.I.O. and Laemmler, C. (1995) Occurrence of haemagglutinating adhesin among virulent and avirulent isolates of Streptococcus suis. Med. Sci. Res. 22: 763-764.

Salasia, S.I.O., Tato, S., Sugiyono, N., Ariyanti, D. and Prabawati, F. (2011) Genotypic characterization of Staphylococcus aureus isolated from bovines, humans, and food in Indonesia. J. Vet. Sci., 12(4): 353-361.

Salasia, S.I.O., Khusnan, Z., Laemmler, C. and Zschock, M. (2004) Comparative studies on phenotypic and genotypic properties of Staphylococcus aureus isolated from bovine subclinical mastitis in central Java in Indonesia and Hesse in Germany. J. Vet. Sci., 5(2): 103-109.

Tirpude, R.J. and Batra, H.V. (2012) Characteristics of Staphylococcus aureus isolated from acute, sub-acute and sub-clinical staphylococcosis in rabbits. World Rabbit Sci., 20: 215-221.

Tiwari, H.K., Sapkota, D. and Sen, M.R. (2008) Evaluation of different tests for detection of Staphylococcus aureus using coagulase (coa) gene PCR as the gold standard. Nepal Med. Coll.J., 10(2): 129-131.

Vancraeynest, D., Haesebrouck, F., Deplano, A., Denis, O., Godard, C., Wildemauwe, C. and K. Hermans K. (2006) International Dissemination of a High Virulence Rabbit Staphylococcus aureus Clone. J. Vet. Med., 53(9): 418-422.

Vaudaux, P.E., François, P., Proctor, R.A., McDevitt, D., Foster, T.J., Albrecht, R.M, Lew, D.P., Wabers, H. and Cooper, S.L. (1995) Use of adhesion-defective mutants of Staphylococcus aureus to define the role of specific plasma proteins in promoting bacterial adhesion to canine arteriovenous shunts. Infect. Immun., 63(2): 585-590.

Vanderhaeghen, W., Hermans, K., Haesebrouck, F. and Butaye, P. (2010) Methicillin-resistant Staphylococcus aureus (MRSA) in food production animals. Epidemiol. Infect., 138: 606-625.

Wibawan, I.W.T., Laemmler, C. and Pasaribu, F.H. (1992) A hemaglutining adesion of group B Streptococci isolates from cases of bovine mastitis mediated adherence to Hela Cell. $J$. Gen Microbiol., 139:2173-1242. 